\title{
Cognitive assessment in patients with Hepatitis $C$ submitted to treatment with Sofosbuvir and Simeprevir or Daclatasvir
}

\author{
Avaliação cognitiva em pacientes com hepatite $C$ submetidos \\ ao tratamento com Sofosbuvir e Simeprevir ou Daclatasvir \\ Maria Rita Polo GASCON', Glaucia Rosana Guerra BENUTE², Elizeu Coutinho MACEDO², Claudio Garcia \\ CAPITÃO ${ }^{4}$, José Ernesto VIDAL ${ }^{5,6}$, Jerusa SMID, Rosa Maria Nascimento MARCUSSO ${ }^{6}$, Mara Cristina Souza \\ de LUCIA ${ }^{7}$, Augusto Cesar PENALVA-DE-OLIVEIRA ${ }^{6}$, Decio DIAMENT ${ }^{8}$
}

\begin{abstract}
Background:Hepatitis C can be defined as an infectious disease that develops an inflammatoryactivity, which may cause an impairment in the central nervous system, may cause cognitive impairments and symptoms of depression. Objective: The objective of this study was to verify the cognitive performance of patients with chronic hepatitis $\mathrm{C}$ before and after treatment with simeprevir, sofosbuvir, and daclatasvir. Methods: A prospective study was carried out in three stages: before, right after treatment, and six months after. Fifty-eight patients under clinical follow-up were evaluated at the Emílio Ribas Infectology Institute, in São Paulo, Brazil. The following instruments were used: sociodemographic questionnaire, Lawton's Scale, Beck's Depression Inventory, and a battery of neuropsychological tests that evaluated: intellectual function, memory, attention, executive function, and motor and processing speed). For statistical analysis, the analyses described (mean, frequency, and standard deviation), chi-square, and ANOVA were used. Results: Most of the participants were male ( $n=30,51.7 \%$ ), with a mean of $58.23 \pm 8.79$ years, mean schooling of $9.75 \pm 4.43$ years. Comparing the results of neuropsychological evaluations (before, just after completion of drugs, and six months), a significant improvement was observed in relation to the acquisition of new knowledge $(p=0.03)$, late visual memory $(p=0.01)$, and tendency towards alternate attention ( $p=0.07$ ). Conclusion: The treatment of the hepatitis $C$ virus improved cognitive performance, especially in relation to memory.
\end{abstract}

Keywords: Hepatitis C; Cognitive Disorders; Combined Modality Therapy.

\begin{abstract}
RESUMO
Introdução: A hepatite C pode ser definida como uma doença infecciosa, que se desenvolve por uma atividade inflamatória, que pode gerar um comprometimento no Sistema Nervoso Central, podendo ocasionar prejuízos cognitivos e sintomas de depressão. Objetivo: 0 objetivo deste estudo foi verificar o desempenho cognitivo de pacientes com hepatite C crônica antes e após o tratamento com simeprevir, sofosbuvir e daclatasvir. Métodos: Foi realizado um estudo prospectivo em três etapas: antes, logo após o tratamento e seis meses depois. Foram avaliados 58 pacientes em acompanhamento clínico no Instituto de Infectologia Emílio Ribas, em São Paulo, Brasil. Foram utilizados os seguintes instrumentos: questionário sociodemográfico, Escala de Lawton, Inventário de Depressão de Beck e uma bateria de testes neuropsicológicos que avaliaram: função intelectual, memória, atenção, função executiva e velocidade motora e de processamento). Para análise estatística, foram utilizadas as análises descritas (média, frequência e desvio padrão), qui-quadrado e ANOVA. Resultados: A maioria dos participantes era do sexo masculino ( $n=30,51,7 \%$ ), com média de 58,23 $\pm 8,79$ anos, escolaridade média de 9,75 $\pm 4,43$ anos. Comparando os resultados das avaliações neuropsicológicas (antes, logo após a finalização dos medicamentos e seis meses), observou-se melhora significativa em relação à aquisição de novos conhecimentos $(p=0,03)$, memória visual tardia $(p=0,01)$ e tendência em relação a atenção alternada ( $p=0,07)$. Conclusão: $\mathrm{O}$ tratamento do vírus da hepatite $\mathrm{C}$ melhorou o desempenho cognitivo, principalmente em relação à memória.
\end{abstract}

Palavras-chave: Hepatite C; Transtornos Cognitivos; Terapia Combinada.

\footnotetext{
Universidade de São Paulo, Faculdade de Medicina, Hospital das Clínicas, Departamento: Divisão de Psicologia, São Paulo SP, Brazil. 2Universidade de São Paulo, Faculdade de Medicina, Hospital das Clínicas, Cliníca de Obstetricia - Pós-Graduação, São Paulo SP, Brazil. ${ }^{3}$ Universidade Presbiteriana Mackenzie, Departamento de Psicologia, São Paulo SP, Brazil.

Instituto de Infectologia Emilio Ribas, Departamento de Psicologia, São Paulo SP, Brazil.

5Universidade de São Paulo, Faculdade de Medicina da USP, Departamento de Moléstias Infecciosas e Parasitárias, São Paulo SP, Brazil.

${ }^{6}$ Instituto de Infectologia Emilio Ribas, Departamento de Neurologia, São Paulo SP, Brazil.

7Centro de Estudos Psicologia Saúde, São Paulo SP, Brazil.

${ }^{8}$ Instituto de Infectologia Emilio Ribas, Departamento de Doenças Infecciosas, Grupo de Hepatites, São Paulo SP, Brazil.

Maria Rita Polo GASCON (D) https://orcid.org/0000-0002-3260-9000; Glaucia Rosana Guerra BENUTE (DD https://orcid.org/0000-0003-0781-1976;

Elizeu Coutinho MACEDO (D) https://orcid.org/0000-0003-1412-3450; Claudio Garcia CAPITÃO (ID https://orcid.org/0000-0001-5321-3286;

José Ernesto VIDAL (D) https://orcid.org/0000-0001-5000-717X; Jerusa SMID (D) https://orcid.org/0000-0001-9513-0964;

Rosa Maria Nascimento MARCUSSO (iD https://orcid.org/0000-0002-8396-0263; Mara Cristina Souza de LUCIA;

Augusto Cesar PENALVA-DE-OLIVEIRA (D) https://orcid.org/0000-0002-4084-7973; Decio DIAMENT (D) https://orcid.org/0000-0003-0147-2061

Correspondence: Maria Rita Polo Gascon; E-mail: mariaritapolo@yahoo.com.br

Conflict of interest: There is no conflict of interest to declare.

Received on November 22, 2019; Received in its final form on February 02, 2020; Accepted on February 06, 2020.
} 


\section{INTRODUCTION}

Currently, hepatitis $\mathrm{C}$ is one of the most common causes of chronic liver disease all over the world. It is estimated that approximately 170 to 200 million persons all over the world are infected by HCV. In Brazil, the prevalence is approximately $1.4 \%$ of the population, representing about two million persons affected ${ }^{1,2,3}$. In respect to cognition and neuropsychiatric aspects, parameters below the population's average are observed, with greater highlights in the literature for attention deficit, concentration, memory, information processing, and visual-motor processing speed ${ }^{4,5,6,7,8}$. Raison et al. ${ }^{9}$ state that among the adverse neuropsychiatric effects, there are depression, anxiety, fatigue, delirium, extreme irritability states, agitation, and in some cases development of psychosis. The depressive symptoms are found in about $40 \%$ of the patients with harmful effects both in the quality of life as well as in the conformity with the treatment.

Several evidence lines suggest that the cognitive dysfunction and the depressive symptoms are related with the release of post-inflammatory cytokines caused by HCV infection of the central nervous system, which replicates in the mononuclear peripheral blood cells and in the bone marrow, precursor of the microglial cell in the brain. The putative inflammatory cytokines are interleukin-1, 4 , and 6 , the tumor necrosis factor- $\alpha$ and interferon- $\alpha$, which could cross the blood-brain barrier and affect the functioning of the brain ${ }^{10}$. Thus, the HCV is introduced in the central nervous system through a "Trojan horse" mechanism ${ }^{4,11,12,13}$. However, no clear correlation between the HCV viral load and cognitive impairment could be demonstrated ${ }^{14}$. The presence of $\mathrm{HCV}$ in the liver tissue stimulates the endogenous production of interferon and this substance interferes with the metabolism of tryptophan and reduces serotonin production in the brain. Therefore, this would represent a pretense induction mechanism or predisposition to depression ${ }^{15}$.

The use of interferon in HCV-infected patients present side effects in several studies, with those most mentioned being: fever, headache, chills, myalgia, asthenia, arthralgia, and anorexia ${ }^{16}$, with asthenia being the most frequent symptom in patients diagnosed with hepatitis C. Others neuropsychiatric symptoms frequently reported by patients are irritability, weariness, emotional instability and depression ${ }^{17}$.

As of the second half of 2015, the STD/Aids department of the Ministry of Health announced that the patients with Hepatitis C under treatment at SUS (National Unified Health System) would have more drugs available for treatment: sofosbuvir, simeprevir, and daclatasvir. The new treatments have a cure rate close to $90 \%$, significantly higher than all the treatments used to this moment, and duration between 12 to 24 weeks, against 48 weeks duration for the previous therapy. Another advantage lies in the fact that the treatment is oral, proportioning greater quality of life and comfort for the patient ${ }^{18}$.
The indications for administration of each medication were: Simeprevir was administered to adult patients with HCV infection genotype 1, treatment virgins, or that failed previous treatment for interferon, with HIV-1 coinfection and adults with genotype $4 \mathrm{HCV}$ infection (virgin or previously treated $)^{19}$. Sofosbuvir should be administered to patients with infection by HCV genotypes 1, 2, or 3, including those with HCV / HIV-1 coinfection ${ }^{20}$. Daclastavir is indicated for combined with other agents for treatment of chronic hepatitis $\mathrm{C}$ virus $\mathrm{HCV}-1$ infection in adults with compensated liver disease (including cirrhosis) ${ }^{21}$.

The purpose of this study was to check the cognitive performance of patients with chronic hepatitis $\mathrm{C}$ before and after treatment with simeprevir. Sofosbuvir and daclatasvir.

\section{METHODS}

A prospective observational study was carried out in three stages: before, soon after treatment (up to three weeks after final treatment), and six months afterwards. The participants were selected at Instituto de Infectologia Emílio Ribas, tertiary referral hospital in the State of São Paulo, Brazil, in the period from 2015 to 2017. The criteria for inclusion contemplated outpatients with minimum 18 years of age, minimum four years education, and eligible for antiviral treatment for chronic infection by HCV. The exclusion criteria were: not having completed the three proposed evaluations, use of psychotropic substances, hepatic encephalopathy, HIV, HTLV coinfected patients or chronic hepatitis B, hepatocarcinoma, cirrhosis in transplant waiting list, transplanted patients with HCV relapse infection, previously documented dementia, and major depression.

The neuropsychological battery consisted of the following tests: Estimated Intellectual Function: Vocabulary ${ }^{22}$ and Matrix Reasoning ${ }^{22}$ from WAIS III scale; Memory: Operational- Digit span subtest ${ }^{22}$ - WAIS-III, Auditory Episodic Memory - Hopkins Verbal Learning Test (HVLT) ${ }^{23}$, Visual Memory: Rey Complex Figures ${ }^{24}$; Visuoconstruction: Rey Complex Figures (copy) ${ }^{24}$; Attention: Sustained Trail Making $\mathrm{A}^{25}$, Alternating - Trail Making $\mathrm{B}^{25}$, Selective - Stroop ${ }^{25}$; Processing Speed: Digit Symbol Coding subtest $^{22}$ - WAIS-III; Executive Function: Phonemic Verbal Fluency (F.A.S.) ${ }^{26}$ and Category (animals) ${ }^{27}$ and Motor Speed: Grooved pegboard test ${ }^{28}$. To analyze the impact in the daily life activities, the Lawton ${ }^{29}$ Scale was used, while, the evaluation of depressive symptoms was made with Beck's Depression Inventory ${ }^{30}$. Alcohol intake was evaluated for all patients by means of the ASSIST Test ${ }^{31}$. No patient had use of low, moderate, and high-risk substances for the use of alcohol and drugs, if they had, they would have been excluded from the study. Cigarette smoking patients were not excluded. 
After neuropsychological assessment, the following categories, adapted from the Diagnostic and Statistical Manual of Mental Disorders (DSM-V) ${ }^{32}$, were created:

- No neurocognitive disorder: no evidence of cognitive decline and independence in daily activities. Minor neurocognitive disorder: evidence of modest cognitive decline from a previous performance level, in one or more of the evaluated domains, based on the concerns of the individual, and a decline in neurocognitive performance, typically involving test performance within the range of one and two standard deviations below appropriate norms on formal. The cognitive deficits are insufficient to interfere with independence.

- Major neurocognitive disorder: There is evidence of substantial cognitive decline from a previous performance level in one or more of the domains outlined above based on the concerns of the individual, and a decline in neurocognitive performance, typically involving test performance in the range of two or more standard deviations below appropriate norms on formal. The cognitive deficits are sufficient to interfere with independence.

A sociodemographic questionnaire was applied with questions referring to age, gender, education, diagnosis time, virus transmission, drugs in use, and presence of cirrhosis. The genotype was collected in the hospital's laboratory exam system.

For statistical analysis, described analysis (mean, frequency, and standard deviation), chi-square (for analysis of category variables [frequencies]), and ANOVA (to test differences of cognitive performance and of depression in the three moments of the evaluation) were used. The value of statistical significance adopted was $5 \%$.

\section{RESULTS}

One hundred and forty-six patients were consecutively recruited by telephone contact after the medical information that they were eligible and would start with the new drugs for hepatitis treatment. Eighty-eight patients were excluded (Figure 1). The 58 remaining made the three evaluations foreseen in the study.
Most of the patients were of male gender, with average of 58.23 years of age, with genotype $1 \mathrm{HCV}$, and absence of advanced hepatic fibrosis. The main form of virus transmission was by blood transfusion ( 20 cases $-34.5 \%$ ). In Table 1 , the main characteristics of the patients in the baseline are presented.

During antiviral treatment, the patients kept adequate hemoglobin levels. None of the participants showed a problematic consumption of alcohol, mental confusion, or hepatic encephalopathy in the inclusion, during and after the treatment. Thirty-three (56.8\%) patients presented other associated diseases or conditions, like high blood pressure - 14 (24.1\%), diabetes mellitus - 11 (18.9\%), hypothyroidism $-4(6.8 \%)$, cholesterol -2 (3.4\%), rheumatism (this information was provided by the patient), rheumatoid arthritis, pangastritis, and osteoporosis $-1(1.7 \%)$. All patients showed independence for daily living activities according to the Lawton Scale criteria.

From the 58 patients, $14(24.1 \%)$ underwent treatment with sofosbuvir+simeprevir, $17 \quad(29.3 \%)$ with sofosbuvir+daclatasvir, 26 (44.8\%) sofosbubir+daclastavir+ri bavirin, and 1 (1.7\%) with sofosbuvir+ribavirin. All patients presented a negative virological test result for hepatitis $\mathrm{C}$.

Comparing the results of the neuropsychological evaluations (before, soon after conclusion, and six months after conclusion of the use of HCV drug), a significant improvement was observed in relation to the acquisition of new

Table 1. Main characteristics in the baseline.

\begin{tabular}{lc}
\hline Characteristics & Mean \pm SD \\
\hline Age & $58.23(8.79)$ years \\
Education & $9.75(4.43)$ years \\
Gender & \\
$\quad$ Male & $30(51.7 \%)$ \\
$\quad$ Female & $28(48.3 \%)$ \\
Evolution time & $10.73(8.00)$ years \\
Transmission mechanism & \\
$\quad$ Sexual & $5(8.6 \%)$ \\
Transfusion & $20(34.5 \%)$ \\
Sharp objects & $14(24.1 \%)$ \\
Not known & $19(32.8 \%)$ \\
Cirrhosis & $28(48.3 \%)$ \\
\hline
\end{tabular}

SD: standard deviation.

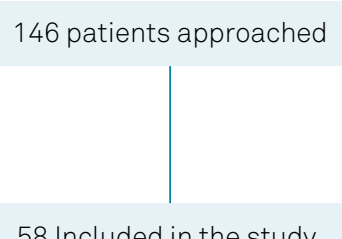

58 Included in the study

Figure 1. Flow diagram.
27 - disagreement with inclusion criteria

18 - did not accept participating in the study

14 - missed the appointment

29 - did not complete the three evaluations 
knowledge (HVLT - immediate recall auditory episodic memory, $\mathrm{p}=0.03$ ), delayed visual memory (Rey Figure delayed recall, $\mathrm{p}=0.01$ ), and a tendency for alternating attention (Trail Making B, $\mathrm{p}=0.07$ ). No significant improvement was observed in other neurocognitive domains after treatment, as shown in Table 2.

After antiviral treatment, it was possible to verify an increase in the frequency of patients with preserved cognitive function, above all on those who presented memory variation. In contrast, it was not observed a change in the cognitive profile of patients who presented non-amnestic cognitive impairment, as shown in Table 3.

An improvement in the depressive symptoms, with increase in the frequency from 67.23 to $84.47 \%$ in the minimum and mild degrees, was observed $(\mathrm{p}=0.079)$. The patients that presented severe degree before the start of the treatment maintained the same intensity at conclusion (Table 4).

No significant correlations were observed between form of transmission $(\mathrm{p}=0.70)$, age $(\mathrm{p}=0.47)$, gender $(\mathrm{p}=0.48)$, education $(p=0.74)$, time since diagnosis $(p=0.64)$, and presence

Table 2. Neuropsychological domains in patients before and after antiviral treatment.

\begin{tabular}{|c|c|c|c|c|}
\hline Test & $1^{\text {st }}$ Evaluation & $2^{\text {nd }}$ Evaluation & $3^{\text {rd }}$ Evaluation & $p$-value \\
\hline Vocabulary & $32.82(1.15)$ & $36.13(1.05)$ & $34.93(1.24)$ & 0.12 \\
\hline Matrix reasoning & $9.79(0.61)$ & $10.00(0.69)$ & $10.29(0.71)$ & 0.87 \\
\hline Estimated IQ & $93.58(2.01)$ & $97.17(1.40)$ & $97.62(1.48)$ & 0.17 \\
\hline Digit Span & $12.62(0.95)$ & $11.20(0.34)$ & $11.51(0.35)$ & 0.24 \\
\hline Immediate HVLT & $22.10(0.65)$ & $24.08(0.66)$ & $24.20(0.59)$ & 0.03 \\
\hline Delayed HVLT & $7.93(0.41)$ & $8.18(0.30)$ & $8.18(0.24)$ & 0.81 \\
\hline Recognition HVLT & $10.08(0.26)$ & $10.31(0.24)$ & $10.44(0.17)$ & 0.54 \\
\hline Rey-copy & $27.99(0.94)$ & $28.26(0.95)$ & $34.16(5,95)$ & 0.36 \\
\hline Rey immediate & $11.28(0.89)$ & $12.91(1.07)$ & $13.63(1.01)$ & 0.19 \\
\hline Rey delayed & $10.48(0.79)$ & $13.10(0.99)$ & $14.03(0.95)$ & 0.01 \\
\hline Trail A & $53.15(3.24)$ & $47.34(3.04)$ & $47.86(2.83)$ & 0.35 \\
\hline Trail B & $141.78(14.68)$ & $110.98(6.90)$ & $114.74(8.24)$ & 0.07 \\
\hline Stroop & $39.63(2.51)$ & $46.81(4.94)$ & $40.15(3.62)$ & 0.33 \\
\hline Digit Symbol Coding & $37.22(1.83)$ & $40.29(2.04)$ & $41.06(1.97)$ & 0.34 \\
\hline F.A.S. & $30.51(1.40)$ & $29.77(1.26)$ & $31.03(1.13)$ & 0.78 \\
\hline Animals & $16.01(1.13)$ & $14.74(0.47)$ & $14.91(0.46)$ & 0.43 \\
\hline Grooved DH & $86.81(3.42)$ & $86.10(3.41)$ & $87.70(3.76)$ & 0.95 \\
\hline Grooved NDH & $95.39(3.81)$ & 89.71 (3.65) & $93.36(4.56)$ & 0.60 \\
\hline
\end{tabular}

IQ: intellectual coefficient; HVLT: Hopkins Verbal Learning test; F.A.S: Fluency Task Test, DH: dominant hand; NDH: non-dominant hand.

Table 3. Distribution of the frequency of cognitive impairment before and after antiviral treatment.

\begin{tabular}{|c|c|c|c|c|}
\hline & $1^{\text {st }}$ Evaluation & $2^{\text {nd }}$ Evaluation & $3^{\text {rd }}$ Evaluation & $\mathrm{p}$-value \\
\hline Preserved cognitive function & $16(27.5 \%)$ & $23(39.6 \%)$ & $29(50 \%)$ & 0.01 \\
\hline Amnestic $\mathrm{MCl}$ - single-domain & $5(8.6 \%)$ & $4(6.8 \%)$ & $4(6.8 \%)$ & 0.19 \\
\hline Amnestic MCl multiple-domain & $16(27.5 \%)$ & $11(18.9 \%)$ & $4(6.8 \%)$ & 0.01 \\
\hline Non-amnestic $\mathrm{MCl}$ - single-domain & $8(13.7 \%)$ & $8(13.7 \%)$ & $9(15.5 \%)$ & 0.19 \\
\hline Non-amnestic MCI multiple-domain & $13(22.4 \%)$ & $12(20.6 \%)$ & $12(20.6 \%)$ & 0.20 \\
\hline
\end{tabular}

$\mathrm{MCl}$ : mild cognitive impairment.

Table 4. Distribution of the frequency of depression.

\begin{tabular}{lccc}
\hline Beck & $1^{\text {st }}$ Evaluation & $2^{\text {nd }}$ Evaluation & $3^{\text {rd }}$ Evaluation \\
\hline Degree - Minimum $(n / \%)$ & $30(51.72)$ & $35(60.34)$ & $35(60.34)$ \\
Degree - Mild $(n / \%)$ & $9(15.51)$ & $7(12.06)$ & $14(24.13)$ \\
Degree - Moderate $(n / \%)$ & $13(22.41)$ & $12(20.68)$ & $3(5.17)$ \\
Degree - Severe $(n / \%)$ & $6(10.34)$ & $4(6.89)$ & $6(10.34)$ \\
\hline
\end{tabular}


or absence of cirrhosis ( $\mathrm{p}=0.34)$, as well as improvement of cognitive performance.

\section{DISCUSSION}

In this study, the neuropsychological performance and frequency of depression in HCV infected patients were compared before the start of treatment, soon after the expected treatment and six months after treatment conclusion. It was observed that the patients presented significant cognitive improvement in the neurocognitive domains of immediate verbal episodic memory, late recall visual memory, and tendency to alternating attention.

The chronic hepatitis $\mathrm{C}$ virus infection could lead to impairment of the central nervous system (CNS) by means of diverse mechanisms. CNS impairment could be due to the presence of the virus in the brain tissue, affecting its function, whether directly by pathogenic effect of the virus in the tissue, or indirectly, by means of the immune-mediated injury mechanism, independent of hepatic dysfunction ${ }^{6}$.

The normal function of the brain could also be affected in the presence of hepatic insufficiency, due to toxic levels of ammonia, leading to the development of hepatic encephalopathy syndrome, condition that promotes the appearance of cognitive and behavioral changes, which could also arise from and be secondary to the side effects of drugs used in the treatment of chronic hepatitis $\mathrm{C}$ virus infection, especially interferon alfa ${ }^{7,33,34}$.

The HCV infected patients could present cognitive changes, characterized by memory loss, conscience fluctuation and disorientation, attention and difficulty in accomplishing plain daily activities, condition known as hepatic encephalopathy, related to the elevation of ammonia serum levels and to astrocytic swelling?. Recent evidences point out that about $30 \%$ of patients infected hepatitis $\mathrm{C}$ virus present cognitive changes, and in part of these individuals, these changes are independent of hepatic dysfunction, viral load, or viral genotype. In patients without cirrhosis, the symptoms characterized by slow thinking and difficulty in concentration are predominant $t^{4,5,6,7,8}$.

Several studies $4,6,33,34,35,36,37$ using neuropsychological tests batteries have demonstrated cognitive impairment of sustained attention, concentration, working memory, processing speed, with greater impairment of sustained attention, and visual-motor processing speed. Studies show not only significant symptoms of attention deficit and executive function, but greater prevalence in the depression, anxiety and fatigue symptoms and impact in the quality of life. Other impaired neuropsychological functions are also observed, such as verbal learning ability, with an increase in the verbal and working memory deficit after the use of interferon and ribavirin ${ }^{33}$. It was observed an increase in the probability of dysfunctions when there is association of hepatic encephalopathy and cirrhosis in the comorbidities presented by HCV bearers ${ }^{6,34}$. However, there is little data available describing the potential reversibility of cognitive disturbances after well-succeeded antiviral treatments.

Byrnes et al. ${ }^{34}$ carried out a magnetic resonance spectroscopy and a battery of neuropsychological tests before, during and after antiviral treatment with interferon and ribavirin in $15 \mathrm{HCV}$ infected patients. They concluded that the eradication of HCV had a beneficial effect on the brain metabolism and better verbal learning and visual and spatial memories. Kraus et al. ${ }^{35}$ carried out a multicentric study including 168 patients with HCV that received antiviral therapy with interferon and ribavirin. Twelve months after conclusion of the antiviral treatment, the patients with sustained virological response (SVR) presented significant improvement in four of five domains (vigilance, shared attention, optical task, and working memory). Barbosa et al. ${ }^{36}$ conducted a study in which they evaluated the cognitive profile of patients submitted to HCV treatment before and after the treatment (24 and 48 weeks), the result showed that the patients that reached $\mathrm{HCV}$ eradication presented significant improvement in the immediate and delayed episodic memory.

Kleefeld et al. ${ }^{37}$ conducted a longitudinal analysis of the cognitive performance of 22 patients $(8 \mathrm{HCV}+, 14 \mathrm{HCV}+/ \mathrm{HIV}+)$ who completed neuropsychological testing at baseline and at week 12 after DAA therapy. At baseline, $54.5 \%$ of the patients met the criteria for cognitive impairment. Follow-up analysis revealed significant improvements in the domains of visual memory/ learning, executive functions, verbal fluency, processing speed, and motor skills but not in verbal learning and attention/working memory. The findings showed that successful DAA treatment leads to cognitive improvements in several domains measured by standard neuropsychological testing.

Marciniewicz et $a .^{38}$, conducted a study to assess brain volume changes and the impact on neuropsychological status in HCV-infected individuals before and after therapy without interferon with direct-acting antiviral agents (DAA). Eleven HCV genotype 1 patients treated with ombitasvir / paritaprevir (ritonavir-boosted) and dasabuvir, with or without ribavirin, underwent brain magnetic resonance imaging (MRI) before and 24 weeks after the end of therapy. After DAA therapy, a statistically significant improvement was observed in the performance of the three tasks of the Rey Complex Figure Test, which allows the evaluation of different functions (attention, planning, work, memory) and also a significant improvement in the percent responses of the Rey, conceptual level in the Wisconsin Card Classification Test (a neurocognitive test for assessing executive function).

In these studies, the patients were submitted to treatment with interferon, but the results on the improvement of the cognitive performance were similar to those found in patients submitted to the new treatment proposed by the Ministry of Health of Brazil, an improvement in relation to the acquisition of new information and visual memory was 
also observed. The big difference was in relation to the side effects. The patients reported only little fatigue and headache, although bearable, whose symptoms occurred only in the first week.

According to the study conducted by Hahn et al. ${ }^{39}$ with 24 patients with chronic HCV infection, before (T1), during (T2: at 4 weeks) and 12 weeks post-treatment with DAA (T3), concluded that DAA exert positive and persistent effects on both fatigue and mood in patients with chronic HCV infection. These extrahepatic benefits are at least partly related to the modulation of TRP metabolism.

In relation to depression, despite the decrease in the frequency of more severe intensities after the treatment was concluded, no statistically significant difference was observed between the mean score before and after treatment, result similar to that observed by Barbosa et al. ${ }^{36}$. It is possible that the greater depression frequency and related symptoms observed before the antiviral treatment reflected, at least in part, the clinical, social, and emotional contexts of the patients.
A limitation of the present study was constituted in the lack of an HCV control group of non-treated patients to exclude some confusion factors, like effect of practice in the tested neurocognitive domains. Another limitation of the study is the possibility of the learning effect of the tests applied.

In conclusion, we demonstrated that the patients that reached HCV eradication presented significant improvement in immediate recall auditory episodic memory and delayed visual memory. However, the frequency of depressive symptoms did not present a statistically significant decrease. The hypothesis for these results may be the treatment of encephalopathy, as well as the elimination of the virus in the central nervous system, since the presence of one of these two factors may cause multifocal lesions in the white substance predisposing the individual to neuropsychological alterations and depression ${ }^{40}$. The additional benefit of the improvement in the neurocognitive impairment after cleansing of HCV with therapy based on the new drugs have clinical implications and the potential of making the cognitive function a valid result of the treatment.

\section{References}

1. Brasil. Ministério da Saúde. Programa Nacional de DST e AIDS Boletim Epidemiológico - Hepatites Virais de 2018. Available from: http://www.aids.gov.br/pt-br/pub/2018/boletim-epidemiologico-dehepatites-virais-2018

2. Focaccia R, da Conceicao OJ, Sette H Jr, Sabino E, Bassit L, Nitrini $\mathrm{DR}$, et al. Estimated prevalence of viral hepatitis in the general population of the Municipality for review only Sao Paulo, measured by a serologic survey of a stratified, randomized and residence based population. Braz J Infect Dis. 1998 Dec;2(6):269-84.

3. Martins T, Narciso-Schiavon JL, Schiavon LL. Epidemiologia da infecção pelo vírus da hepatite C. Rev Ass Med Bras. 2011;57(1):107-12. https://dx.doi.org/10.1590/S010442302011000100024

4. Hilsabeck RC, Perry W, Hassanein TI. Neuropsychological impairment in patients with chronic hepatitis Hepatology. 2002 Feb;35(2):440-6. https://doi.org/10.1053/jhep.2002.31257

5. Hilsabeck RC, Hassanein TI, Carlson MD, Ziegler EA, Perry W. Cognitive functioning and psychiatric symptomatology in patients with chronic hepatitis C.J Int Neuropsychol Soc. 2003 Sep;9(6):84754. https://doi.org/10.1017/S1355617703960048

6. Perry W, Carlson MD, Barakat F, Hilsabeck RC, Schiehser DM, Mathews C, et al. Neuropsychological test performance in patients co-infected with hepatitis C virus and HIV. AIDS. 2005 Oct;19 Suppl 3:S79-84. https://doi.org/10.1097/01.aids.0000192074.18691.31

7. Bragagnolo MA, Teodoro V, Lucchesesi LM, Ribeiro TCR, Tufik S, Kondo M. Detecção de encefalopatia hepatica minima através de testes neuropsicológicos e neurofisiológicos e o papel da amônia no seu diagnóstico. Arq Gastroenterol. 2009 Mar;46(1):43-9. https://doi. org/10.1590/S0004-28032009000100013

8. Kraus MR, Schafer A, Wißmann S, Reimer P, Scheurlen M. Neurocognitive changes in patients with hepatitis $C$ receiving interferon alfa-2b and ribavirin. Clin Pharmacol Ther. 2005;77(1):90-100. https://doi.org/10.1016/j.clpt.2004.09.007

9. Raison CL, Demetrashvili M, Capuron L, Miller AH. Neuropsychiatric adverse effects of interferon-alfa: recognition and management. CNS Drugs. 2005:19(2):105-23. https://doi.org/10.2165/00023210200519020-00002
10. Perry W, Hilsabeck RC, Hassanein T. Cognitive dysfunction in chronic hepatitis C: a review. Dig Dis Sci. 2008 Aug;53:307-21. https://doi. org/10.1007/s10620-007-9896-z

11. Adinolfi LE, Nevola R, Lus G, Restivo L, Guerrera B, Romano C, et al. Chronic hepatitis $C$ virus infection and neurological and psychiatric disorders: an overview. World J Gastroenterol. 2015 Feb;21 (8):226980. https://doi.org/10.3748/wjg.v21.i8.2269

12. Weissenborn K, Krause J, Bokemeyer M, Hecker H, Schüler A, Ennen JC, et al. Hepatitis $C$ virus infection affects the brain-evidence from psychometric studies and magnetic resonance spectroscopy. J Hepatol. 2004 Nov;41(5):845-51. https://doi.org/10.1016/j. jhep.2004.07.022.

13. Senzolo M, Schiff S, D'Aloiso CM, Crivellin C, Cholongitas E, Burra P, et al. Neuropsychological alterations in hepatitis $\mathrm{C}$ infection: the role of inflammation. World J Gastroenterol. 2011 Aug;17:3369-74. https://doi.org/10.3748/wjg.v17.i29.3369

14. Iriana S, Curry MP, Afdhal NH. Neurologic manifestations of hepatitis C virus infection. Clin Liver Dis. 2017 Aug;21 (3):535-42. https://doi. org/10.1016/j.cld.2017.03.008

15. Capuron L, Ravaud A, Neveu PJ, Miller AH, Maes M, Dantzer R. Association between decreased serum tryptophan concentrations and depressive symptoms in cancer patients undergoing cytokine therapy. Mol Psychiatry. 2002;7(5):468-73. https://doi.org/10.1038/ sj.mp.4000995

16. Braga EL, Lyra AC, Nascimento L, Netto E, Kalabrik L, Lyra LGC. Daily interferon induction regimen using different manufactured interferons (alpha-2A or alpha -2B) in combination with ribavirin for treatment of chronic hepatitis C: a prospective randomized study. Arq Grastroenterol. 2006;43(4):275-79.

17. Strauss E. Hepatite C. Rev Soc Bras Med Trop. 2001;34(1):69-82.

18. Brasil. Ministério da Saúde. Programa Nacional de DST e AIDS. Protocolo Clínico e Diretrizes Terapêuticas para Hepatite Viral C e Coinfecções. Brasília: Ministério da Saúde; 2015.

19. Janssen-Cilag Farmacêutica Ltda. OLYSIO (simeprevir) - Bula do profissional de saúde aprovada pela ANVISA. 2015. Available from: http: www.anvisa.gov.br/datavisa/fila-bula/index.asp 
20. Gilead Sciences Farmacêutica do Brasil Ltda. SOVALDI (sofosbuvir) Bula do profissional de saúde aprovada pela ANVISA. 2015. Available from: http: www.anvisa.gov.br/datavisa/fila-bula/index.asp

21. Bristol-Myers Squibb Farmacêutica S.A. DAKLINZA (daclatasvir) Bula do profissional de saúde aprovada pela ANVISA. 2015. Available from: http: www.anvisa.gov.br/datavisa/fila-bula/index.asp

22. Wechsler D.WAIS III- Escala de inteligência para adultos: manual. (Elizabeth Nascimento, Trad.). 1st ed. São Paulo: Casa do Psicólogo;2004.

23. Miotto EC, Campanholo KR, Rodrigues MM, Serrao VT, Lucia MCS, Scaff M. Hopkins verbal learning test-revised and brief visuospatial memory test-revised: preliminary normative data for the Brazilian population. Arq Neuro-Psiquiatr. 2012 Dec;70(12):962-5. https:// dx.doi.org/10.1590/S0004-282X2012001200014

24. Oliveira MS, Rigoni MS. Figuras Complexas de Rey: teste de cópia e de reprodução de memória de figuras geométricas complexas. São Paulo: Casa do Psicólogo; 2010.

25. Campanholo KR, Romão MA, Machado MAR, Serrao VT, Coutinho DGC, Benute GRG, Lucia MCS. Performance of an adult Brazilian sample on the Trail Making Test and Stroop Test. Dement Neuropsychol. 2014;8(1):2631. https://dx.doi.org/10.1590/S1980-57642014DN81000005

26. Spreen O, Strauss E. A compendium of neuropsychological tests: administration, norms, and commentary. $2^{\text {nd }}$ ed. New York: Oxford Univ Press; 1998.

27. Brucki SMD, Malheiros SFM, Okamoto IH, Bertolucci PHF. Dados normativos para o teste de fluência verbal categoria animais em nosso meio. Arq Neuropsiquiatria. 1997;55(1):56-61.

28. Lafayette Instrument. Grooved Pegboard Test - Model 32025. User Instructions. Sagamore Parkaway North, USA: Lafayette Instrument; 2002. Available from: https://www.advys.be/docs/ GroovedPegboardTestManual.pdf

29. Lawton MP, Brody EM. Assessment of older people: self-maintaining and instrumental activities of daily living. Gerontologist. 1969 Autumn;9(3):179-86.

30. Gorestein C, Andrade L. Inventário de depressão de Beck: propriedades psicométricas da versão em português. Rev Psiquiatr Clin. 1998;25(5):245-50.

31. Henrique IFS, De Micheli D, De Lacerda RB, De Lacerda LA, Formigoni ML. Validação da versão brasileira do teste de triagem do envolvimento com álcool, cigarro e outras substâncias (ASSIST). Rev Assoc Med Bras. 2004;50(2):199-206. https://doi.org/10.1590/ S0104-42302004000200039

32. American Psychiatric Association. Manual Diagnóstico e Estatístico de Transtornos Mentais: DSM-5. $5^{\text {th }}$ ed. Porto Alegre: Artmed; 2014.

33. Kraus MR, MPsych AS, Wißmann S, Reimer P, Scheurlen P. Neurocognitive changes in patients with hepatitis $C$ receiving interferon alfa-2b and ribavirin. Clin Pharmacol Ther. 2005;77(1):90-100. https://doi.org/10.1016/j.clpt.2004.09.007

34. Byrnes V, Miller A, Lowry D, Hill E, Weinstein C, Alsop D, et al. Effects of antiviral therapy and $\mathrm{HCV}$ clearance on cerebral metabolism and cognition. J Hepatol. 2012 Mar;56(3):549-56. https://doi.org/10.1016/j.jhep.2011.09.015

35. Kraus MR, Schäfer A, Teuber G, Porst H, Sprinzl K, Wollschläger $S$, et al. Improvement of neurocognitive function in responders to an antiviral therapy for chronic hepatitis C. Hepatology. 2013 Aug;58(2):497-504. https://doi.org/10.1002/hep.26229

36. Barbosa MED, Zaninotto AL, Mazo DFC, Pessoa MG, Souza de Oliveira CPM, Carrilho FJ, et al. Hepatitis C virus eradication improves immediate and delayed episodic memory in patients treated with interferon and ribavirin. BMC Gastroenterol. 2017;17:122. https://doi.org/10.1186/s12876-017-0679-5

37. Kleefeld F, Heller S, Ingiliz P, Jessen H, Petersen A, Kopp V, et al. Interferon-free therapy in hepatitis $\mathrm{C}$ virus (HCV) monoinfected and HCV/HIV coinfected patients, effect on cognitive function, fatigue, and mental healths. J. Neurovirol. 2018;24:557-69. https://doi.org/10.1007/s13365-018-0647-z

38. Marciniewicz E, Podgórski P, Pawłowski T, Małyszcza K, FleischerStępniewska K, Knysz B, et al. Evaluation of brain volume alterations in $\mathrm{HCV}$-infected patients after interferon-free therapy: A pilot study. J Neurol Sci. 2019 Apr;399:36-43. https://doi. org/10.1016/j.jns.2019.02.002

39. Hahn D, Strokes CS, Kauser P, Meyer MR, Lanmert F, Gruenhage F,. Antidepressant effects of direct - acting antivirals against hepatitis C virus — Results from a pilot study. Eur J Clin Invest. 2018;48(12):e13024. https://doi.org/10.1111/eci.13024

40. Bichuetti DB, Oliveira ASB. Manifestações neurológicas nas hepatites virais. Rev Neurociênc. 2005 Sep;13(3):133-7. https://doi. org/10.34024/rnc.2005.v13.10351 